\title{
EMERGENCY CASES AT COUNTERING IMPROVISED EXPLOSIVE DEVICES (C-IED), AND THEIR POTENTIAL MANAGEMENT
}

\author{
Tibor HORVÁTH \\ National University of Public Service, Budapest, Hungary \\ horvathtibor@uni-nke.hu
}

\begin{abstract}
During the military operations in Iraq and later in Afghanistan, the capability of force protection, of providing defence against improvised explosive devices (IEDS), and the organization of training courses aimed at enhancing the knowledge of personnel became increasingly important. Previous analyses clearly pointed out that the largest number of military and civil casualties were claimed by such devices.
\end{abstract}

KEYWORDS: operations, improvised explosive devices, IED, C-IED

\section{Introduction}

Terrorism is a strategy of the use or threat of violence, with the primary purpose to generate fear and disruption, and thus to achieve specific political objectives, or to retain power. Generating fear can accompany and support all forms of violence - from pub brawls to traditional warfare but in the case of terrorism, this relationship is reversed, since the direct victims of violence are related with the real target of terrorist acts only in a symbolic, indirect way, their selection is of secondary significance and mostly just random. Terrorism, as a potential source of danger, was mentioned as early as in the 1999 Strategic Concept of the Alliance, but NATO was actively involved in the fight against terrorism only after the events of $11^{\text {th }}$ September 2001. For the first time in its history, the Alliance invoked Article 5 of the North Atlantic Treaty on collective defence, and began to develop various elements of counter-terrorism. At the Prague Summit in November 2002, NATO's military concept DOI: 10.2478/raft-2019-0011

(C) 2017. This work is licensed under the Creative Commons Attribution-NonCommercial-NoDerivatives 3.0 License. of countering terrorism was adopted, the most important elements of which are: counter-terrorism and defensive measures, managing the consequences of terrorist attacks, "offensive" steps to eradicate terrorism, and military cooperation. This concept also states that the threat of terrorism cannot be overcome by military means alone. Military operations must be coordinated and implemented in line with diplomatic, economic, social, legal and information initiatives. Terrorist threat affects the individual as well as society as a whole, therefore every country must support the fight against terrorism in accordance with the resolution of the UN. This message was emphasized at the UN Summit, where the member states condemned all forms of terrorism, regardless of their purpose. They stated that terrorism is one of the greatest threats to international peace and security. Aerial vehicles and aviation installations are particularly vulnerable to terrorism. Their personnel must pay particular attention to and prepare for: 
- taking specific care that violent acts committed on board an airplane preparing for take-off should be prevented, or isolated, if possible pre-empted;

- preventing the continuation of a terrorist act committed on a landing plane;

- isolating hostage-taking at the airport, and attempts to detain the hostagetakers;

- taking action to detect the infiltration of explosives, weapons in the airport area, and to prevent the use thereof;

- preventing acts aimed at occupying or exploding aircraft on the flight line or technical preparation areas;

- preventing an attack on the main building of the airport, passenger waiting area, transit area, roof terrace;

- preventing an attack on the airport's service stations, the persons working there, or facilities there;

- in the event of forecast or imminent emergencies or incidents at the airport, which endangers the safety of the airport and of aviation.

\section{(IEDs)}

2. Improvised Explosive Devices

Terrorists usually commit their acts with the use of weapons, explosive materials, or with threatening with their use.

The definition of IED: improvised explosive devices are destructive non-industrially produced bombs that have a destructive or lethal effect based on substances that are harmful to health, pyrotechnic devices, or chemicals with an incendiary effect. The purpose of their use is to make people unfit or vehicles unsuitable for combat deployment. IEDs are used to disrupt, destroy, or delay enemy forces, or make them abandon their original intentions to attack. IEDs may be produced on the basis of military or other commercially produced explosives, occasionally a mixture of the two, or other home-made explosive materials.
The structure of the device itself is relatively simple: it consists of an explosive charge and a detonator. However, their form, the ignition methods in use, the explosive power, and the explosive charge may be different. The explosive charge of an IED may be of commercially available materials, but may also be of military explosive materials. However, there is also the danger that extremist elements may deploy IEDs with chemical, biological materials, or radioactive coating (dirty bombs that cause large radioactive contamination).

Traditional, stationary positioned IEDs will only have their impact on their location and their immediate surroundings only.

The blast can be initiated by the target itself (e.g. the weight of a vehicle's wheel), or with the use of remote control, by the person performing the blast. Remote control can be with a cable, or a mobile phone, a garage door remote control, or just a simple rubber tube to create the appropriate pressure to operate a switch. In addition to the "standardization" of new versions of conventional explosives, guerrilla forces have also developed new "delivery" procedures. One of these techniques is the individual suicide bomber who takes 5 to $12 \mathrm{~kg}$ of explosive materials on him, attached to his body or carried in his backpack. In order to achieve a larger impact, the explosive charge is reinforced with nails and bearing balls (or other metal objects).

The Vehicle Borne Improvised Explosive Device (VBIED) is an even more dangerous device, since the amount of explosive that can be detonated is theoretically limited only by the payload capacity of the vehicle. The danger of VBIED is greatly increased by the fact that the attacker can drive the vehicle to the exact target, postpone the act, or even stop it. An American expert compared the dangerousness of the VBIEDs to that of Tomahawk cruise missiles based on their accuracy and explosive power. 
Since $11^{\text {th }}$ September 2001, aircraft have been considered not only as targets, but it has also been clear that they are capable of causing huge destruction as VBIEDs.

The Hungarian Defence Forces face many new challenges in international involvements.

A large number of our soldiers take part in a significant number of international missions, and the importance of serving in a foreign mission will not be depreciated in the future either. Asymmetric warfare typical of the $21^{\text {st }}$ century, and the methods used by adversaries present new tasks for modern armed forces. The assets of terrorists, antigovernment, rebel, or insurgent groups have many of the features of non-traditional warfare. Among these relative new tools and methodologies, Improvised Explosive Devices (IEDs) present one of the most pressing problems. They were first deployed in Iraq and then became one of the main means of attack on ISAF and Afghan government forces in Afghanistan, and is increasingly used by antigovernment forces in Pakistan, India and Russia. These simple devices pose an indiscriminate threat to both soldiers and civilians. This article presents the possible actions of neutralising non-conventional explosive devices, that is Counter Improvised Explosive Devices (C-IED) capabilities within the North Atlantic Treaty Organization (NATO) and in Hungary.

During the military operations in Iraq and then in Afghanistan, the protection of friendly forces, the establishment of the capability of protection against improvised explosive devices (IEDs), and the creation and organization of training courses aimed at enhancing the protection-awareness of the personnel became an increasingly important task. Previous analyses clearly pointed out that the greatest number of military and civilian casualties were exacted by these devices. Although effective countermeasures have reduced the number of IED-related injuries and deaths in certain areas since 2010, IEDs still accounted for nearly $59 \%$ of the losses of coalition forces in 2011. The image is inconsistent because the increasing effectiveness of countermeasures did not generate any reduction in the number of attacks. On the contrary, while the number of victims in the security forces has fallen, more and more attacks exact a heavy toll on civilians. In Afghanistan, the number of detected and neutralised explosive devices was 9,304 in 200915,225 in 2010, and further increased by $9 \%$ to 16,554 in 2011 . The number of civilian casualties increased similarly, by $10 \%$ compared to 2010 , while $60 \%$ of the civilian casualties (more than 4,000 wounded or killed) were caused by such explosives.

\section{NATO's C-IED Activity}

As a result, NATO considers the protection of deployed troops and civilian populations a fundamental task: C-IED activity has been a priority for NATO in recent years. The C-IED program is implemented with the involvement of a number of organizations and institutions and for their coordination and communication an effectively operating organizational structure was established. This activity involves the detection, disarming, and identification of the underlying networks. There is continuous exchange of information among national and international intelligence and security agencies, as well as border and customs authorities and security forces, in the field of mapping hostile networks.

In January 2010, the NATO Command, Control, and Communication Agency (NC3A) elaborated a so-called C-IED Action Plan, which identified the deficiencies that hamper the effectiveness of actions against IEDs and established the necessary steps and financial implications of their implementation. Based on the Action Plan, the activities focused on two areas. On the one hand, on "defeating the 
device", which means detecting and neutralising explosive devices. This area also includes military training, preparation, and technology development, involving various NATO organizations. The other key area of the Action Plan was disrupting the network, which means the elimination of the attacking capabilities of the network. ("Network" includes "customers", sponsors of attackers, planners, and executors: those who deliver, plant, and activate explosive devices on the site.)

The NATO Headquarters in Brussels, the Allied Command Transformation (ACT), Norfolk, Virginia, the United States, made activities against improvised explosives a top priority. In the multitude of programs the International Security Assistance Force Headquarters (ISAF), various centres of excellence (CoEs), and several NATO agencies take part in various programs. Extensive collaboration is also necessary in order to share the experience with developers, gained in different areas of operations. In addition to exchange of experience, the C-IED Action Plan also supports technological developments in the field of defence, which reduce the destructive effects of explosive devices. The resulting relations and joint efforts make it possible to operate a system that can cover the strategic and tactical spectrum of counter-IED activities:

- In August 2010, NATO launched the operation of its Emerging Security Challenges Division, whose purpose is to facilitate the cooperation of NATO's various sectoral experts on the Alliance's security developments. Within this framework, explosive sensors are being developed, as part of the fight against terrorists.

- The NATO Consultation, Command and Control Agency (NC3A) has a central role in cooperation. In line with the needs of mission activities, it conducts research and experiments, facilitating development in the field of technology, cyber defence, and procurement. For example, as part of the NC3A C-IED project, explosive detectors were installed at the airport of Kandahar, which was added to the security system of vehicle inspection and access control. Therefore, the task of NC3A in this field is to provide all the technical needs identified in NATO's C-IED Action Plan. Within NATO, NC3A supports the activities of the Conference of National Armaments Directors (CNAD), and an anti-terrorism program, the so-called Defence Against Terrorism Program of Work (DAT PoW), where research is necessary to develop and test new technologies and testing procedures. The organization does not only provide technology, but also contributes to its correct and effective use in theatre. The joint procurement of technologies since 2010 has been supported by NATO, which proved useful in cost reduction.

- The above-mentioned CNAD elaborated cooperation in the field of joint multinational arms programs, in line with the goals set by the NATO Secretary General. A total of 19 initiatives were formulated in the draft, including common assets, procurement, joint research on new technologies, technological research collaboration, and joint development of assets as part of the C-IED Materiel Roadmap. CNAD has set up a Voluntary National Contribution Fund in order to support multinational projects in the C-IED Action Plan. Such projects include pre-intervention training for soldiers, that is Weapons Intelligence Teams (WIT).

\section{Training Cooperation}

NATO places great emphasis on training the troops, because it is essential that the soldier deployed in an area of operations should know the new environment in which he will move, know 
the circumstances in which he will work. NATO, through the ACT, manages training programs and training courses to prepare the units before deployment in IED-infected areas. The most important aspects of the C-IED training are how to stop the attacking network before their planting the explosive device, and the detection and safe neutralisation of IEDs before detonation.

SACT provides a number of courses through the C-IED Integrated Product Team. Through the Staff Officer Awareness Course, Weapons Intelligence Team Course (WIT), and the Voluntary Contribution Fund, "train the trainer" courses (C-IED $\mathrm{TtT} / \mathrm{T} 3$ ) were also launched. As part of this, since 2010, for example, British soldiers have been training Afghan National Army (ANA) troops to acquire C-IED techniques.

Throughout the training, NATO cooperates with a number of centres of excellence, which also provide the military units with the right information and knowledge about the threatened areas, thus allowing a significant increase in security and reduction of losses. Based on the Memorandum of Understanding signed on $23^{\text {rd }}$ June 2010, the C-IED Centre of Excellence $(\mathrm{CoE})$, based in Madrid, Spain, was integrated into the Alliance. Its fundamental purpose is to support NATO and its partners with the help of the CoE's expert team in the fight against improvised explosive devices. The mission of the Centre is to reduce the threat posed by IEDs in attacks by insurgents/terrorists at troops deployed by the Alliance's nations. It also plays a leading role in testing integrated explosive detection technologies in collaboration with private-sector actors. The C-IED CoE is regularly supported by France, Germany, the Netherlands, Portugal, Romania, the United States and Hungary.

The centre has been organising two types of training courses since its establishment: for staff officers the so-called Staff Officer Awareness Course (SOAC), which provides comprehensive knowledge on the counter-IED system, on communication with combat troops at operations level. The other one is the WIT Course, which enables the participants to collect and analyse information on bomb attacks in the rea of operations in order to prevent possible future attacks. The intelligence available in this way increases the effectiveness of NATO's anti-network operations.

For two years the WIT courses, set out in the NATO C-IED Action Plan, provided pre-deployment training outside the area of operations for troops preparing for a mission in Afghanistan. Between $8^{\text {th }}$ and $27^{\text {th }}$ January 2010, the first Hungarian WIT course was organized by NATO-SACT, and conducted at the Central Training Base of the Hungarian Defence Forces, in Szentendre. Soldiers from different nations having graduated from there are able to perform top-level weapons detection tasks. Hungary provides the conduct of courses, training facilities, and equipment.

Since the protection capabilities against explosive devices were identified as an area of serious deficiency within the Alliance, besides Spain Slovakia also increased this capacity with significant contributions and set up an Explosive Ordnance Disposal (EOD) CoE in Trenčín to prepare for C-IED activities, which is the first international military organization in the country. The main profile of the centre is explosive ordnance disposal, and not the activities against networks that install explosives, thus it is a proper complement to the other pillar of NATO's dual purpose.

The Czech Republic, France, Hungary, Romania and Poland which joined in 2011 are members of the EOD-CoE. The Centre provides support for a variety of operations and practices and establishes links with NATO, NATO member states, partners, as well as international organizations. The training courses focus on standardization, doctrine 
development, and the development of EOD and Counter-IED technologies. The Centres of Excellence in Spain and Slovakia cooperate with centres whose work is in connection with IED-infested areas. These are as follows: Military Engineering (MILENG) $\mathrm{CoE}$ in Ingolstadt, Germany, Defence Against Terrorism (DAT) CoE in Ankara, Turkey, Human Intelligence (HUMINT) CoE in Oradea, Romania, and the Military Medical (MILMED) $\mathrm{CoE}$ in Budapest, Hungary.

Based on the ACT's plans, a series of Attack the Network Tactical Awareness Courses (C-IED ATAC) was organized six times in 2011. This year's first course was held between $20^{\text {th }}$ and $25^{\text {th }}$ February at the Joint Force Training Centre (JFTC), in Bydgoszcz, Poland, where the participants came to the 30-strong international group from Austria, Bulgaria, Canada, Estonia, Germany, Italy, Poland, Sweden and Tunisia. The theoretical and practical elements of the course focused on how to cut off insurgents from their resources, how to prevent them from producing and installing explosive devices. The soldiers could learn more about how to attack and weaken the networks of insurgents, and the IEDs planted in the theatre. The next C-IED ATAC course will be held from $10^{\text {th }}$ to $14^{\text {th }}$ September, maintaining a high pace of training to compensate the attacks growing year-on-year.

\section{Hungarian Involvement in International C-IED Activities}

The initiative launched at the 2006 Riga Summit set the goal to establish close cooperation among national training activities. Since Hungary took over the operation of a Provincial Reconstruction Team (PRT) in Afghanistan from $1^{\text {st }}$ October 2006, it was proposed that Hungary should be the venue of conducting international courses.

The NATO Allied Command Transformation (ACT), in cooperation with the Operations and Training Department of the Ministry of Defence, hosted the NATO Operational C-IED Seminar in Hungary, at the MH Central Training Base in Szentendre between $8^{\text {th }}$ and $12^{\text {th }}$ December 2008. This program has facilitated the exchange of operational experience between NATO and the Partnership for Peace (PfP) countries.

Since then the Central Training Base has served as a permanent venue for international courses that have been held regularly 2011 saw a qualitative change when the HDF Central Training Base and Kinizsi Pál Non-Commissioned Officer Training School were integrated. The training programs continued to be of high quality both at domestic and international levels at the newly established NCO Academy. In the very same year, the Academy, as a result of preparations since 2008, won NATO accreditation for the C-IED T3 course and the NATO "Selected Course" qualification. The Command of the unit received the accreditation document from the ACT representative on $22^{\text {nd }}$ March 2012, which provides the right to organize and execute the training courses. This means that Hungary plays a leading role in the training of countering non-traditional explosive devices, as well as in medical support and regional airspace control.

A meeting of Central European C-IED training experts was also held in Szentendre on $29^{\text {th }}$ February 2012. This event was preceded by the 2010 initiative launched by the Austrian-Hungarian defence policy directors in the field of defence cooperation of six countries in the Central European region (Austria, Czech Republic, Croatia, Hungary, Slovakia, and Slovenia). The one-day conference was attended by Hungarian, Austrian, Slovakian and Czech experts who reviewed the co-operation opportunities in C-IED training courses and the basic principles of C-IED activities, as well as the links between the domestic and international training systems. 
Through NATO accreditation, Hungarian capabilities became an integral part of the Alliance training system, which requires the Hungarian Defence Forces to perform at high standards consistently. This motivated the HDF NCO Academy to hold its annual evaluation and tasking conference on $26^{\text {th }}$ March 2012. The meeting was attended by Lieutenant General Zoltán Orosz, Brigadier General Tibor Bozó, Chief of the GS Personnel Department, Brigadier General István Baráth, Chief of the HDF JFC Logistics Command, Colonel István Juhász, Acting Head of the GS Training Department, and Lieutenant Colonel László Korcsog., Acting Director of the HDF Kinizsi Pál NCO School was also present. The main task identified for the future was to maintain the high standards of training and preparation, to properly manage the resources available and to maintain effective leadership along these lines.

The main drive of training is that the protection of the lives of soldiers - and civilians - is a priority on the international stage as well. Therefore, in addition to training and skill-development courses that improve the capabilities of soldiers preparing for a mission, there is also a need for an adequate level of external protection. The sense of security is greatly influenced by the protective features of the assets and technical systems used by soldiers. However, the armed forces have a twofold role in this area: on the one hand, they have to provide appropriate technology and assets, and on the other hand, the skills for their effective use. While expertise is available, the hardware necessary for force protection is extremely expensive, which makes the allocation of necessary funding in the budget rather difficult. With this in mind, it is worth reviewing the most important assets that the Hungarian Defence Forces provides to their troops for protection against improvised explosive devices.
For a long time, only armoured Humvees (High Mobility Multipurpose Wheeled Vehicles - HMMWV), all-terrain vehicles, could be used for off-road traveling in Afghanistan. They have been in use by the Hungarian Provincial Reconstruction Team (PRT) and Operational Mentoring and Liaison Team (OMLT) since 2009. Hungary received 14 vehicles of this type from the United States in 2011. However, these personnel carriers are far from providing full protection.

Real protection can only be achieved by mounting a major amount of armour plates on the vehicles, which is impractical, as increased weight also results in a significant reduction of performance (lower speed and higher consumption). The HMWV's flat chassis is also a disadvantage, as the blast of roadside bombs directly impacts the bottom of the vehicle. However, the newly developed NaviStar Maxxpro MRAP-1 (Mine Resistant Ambush Protected) transport vehicle, considered to be the "grandson of Humvee", offers a solution to all these problems. Thanks to the V-shaped chassis, the vehicle is able to withstand the impact of an explosive charge of up to 7 kilograms because it is able to deflect the shock wave of the IED explosion to the sides.

US soldiers have been using MRAPs since 2007, and the first vehicles arrived at the Hungarian camp in Afghanistan (Camp Pannonia) in early January 2011. The direct predecessor of this type is the TSG/FPI Cougar, which provides protection for Hungarian UXO personnel. One of them is in the Area of Operations and one in Hungary. By comparison: a Humvee costs USD 60,000 while its armoured version may cost as much as three times more, while MaxxPro's market price is at least half a million dollars. Driving and maintenance of MaxxPro were practiced by the Hungarian service people with the help of American trainers. Because of the rollover risk caused by the high suspension 
of the vehicle and its relatively high centre of gravity, these vehicles are not easy to drive. (High suspension above the road surface reduces the energy of the explosion on the chassis).

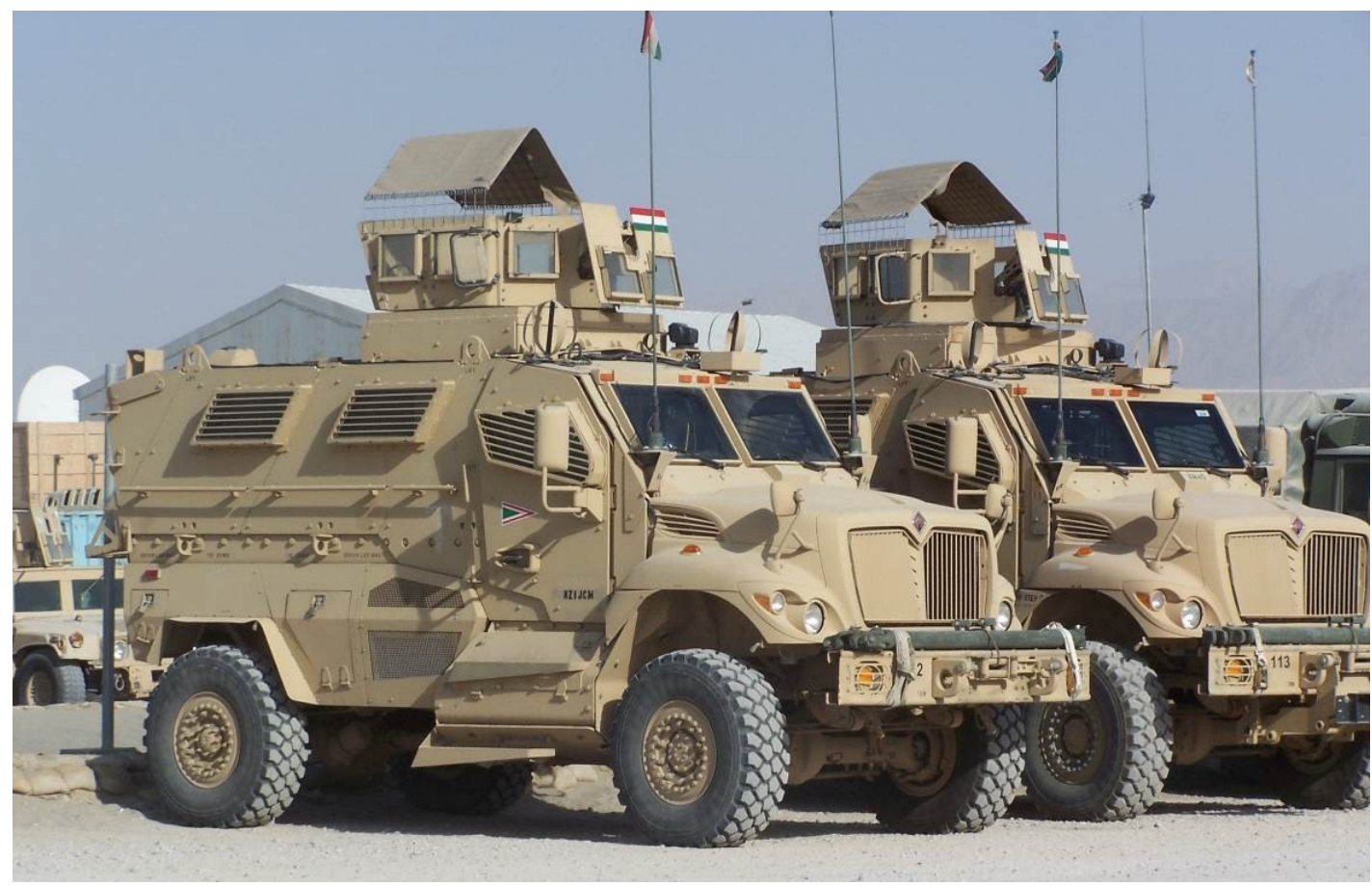

Figure no. 1: Hungarian MaxPros in Mazar-e Sharif

After several accidents, there the HDF National Support Element. appeared a growing need for proper driver training - so in August 2011, "Rollover" training was organized in Mazar-e Sharif. The training was directed and conducted by Practicing was supported by a real-life simulator, which can be used to easily develop the skills of movements during and after the rollover, including the safe exit.

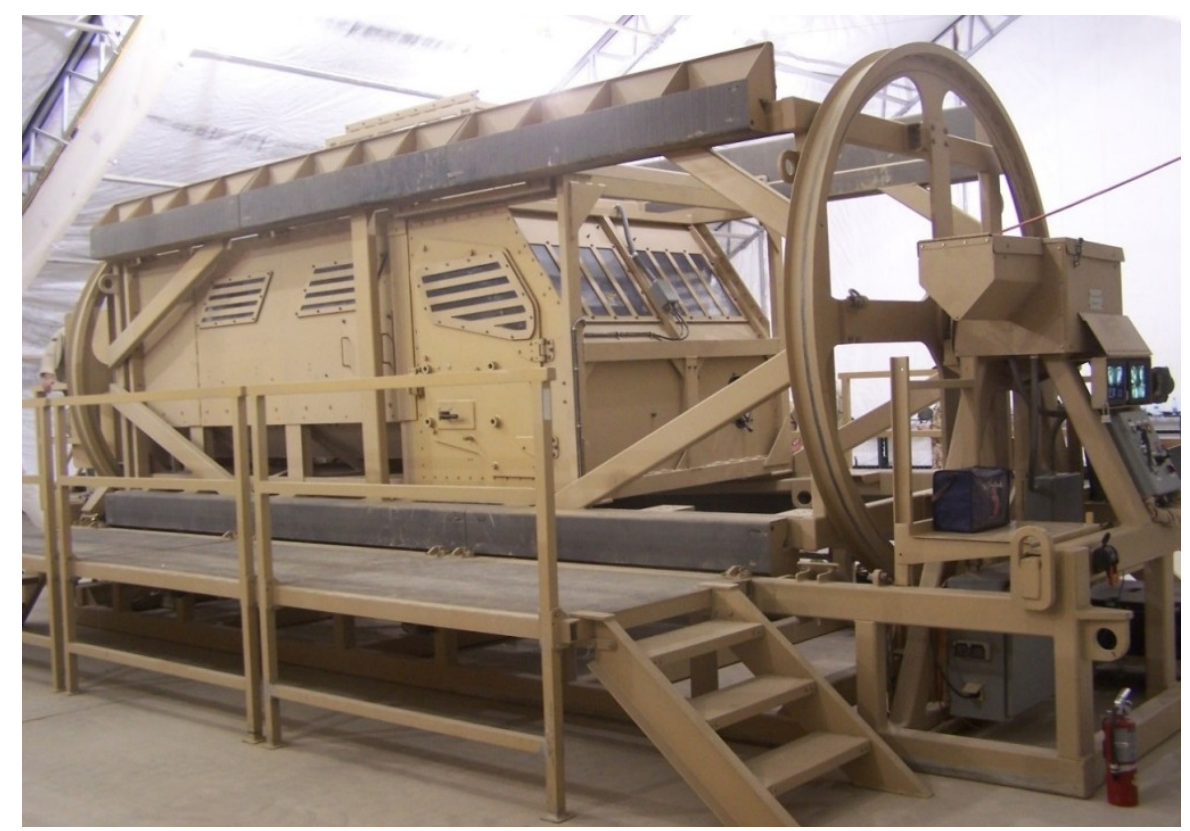

Figure no. 2: A rollover simulator 
Jamming systems with which these vehicles can be equipped play an important role in the protection against IEDs. This is important because, if the ignition of the explosive device is remote controlled (Radio Controlled IED - RCIED), jammers can cause interference at its operating wavelength and the convoy can move safe and sound. Jamming is continuous, broadband and high-power. However, in the covered frequency range, "holes" are created by the influence of friendly communications or operational connections, as their operation must be ensured despite the jamming. Due to the rapid response of the opponent, radio-controlled IEDs can be operated outside the standard bands or at low frequencies (e.g. with the use of mobile phones, garage door remote controls), making the jamming of the signal difficult.

Another possibility is to have a robot vehicle travel in front of a convoy to indicate the presence of suspicious objects. However, this solution is not always feasible (for example, in urban transport), and is not practical either as it slows down the movement of the convoy. The Hungarian Defence Forces uses the Andros F6A heavy EOD robot to detect and destroy explosive ordnance, in addition, TeleMAx light EOD robot is also in use.

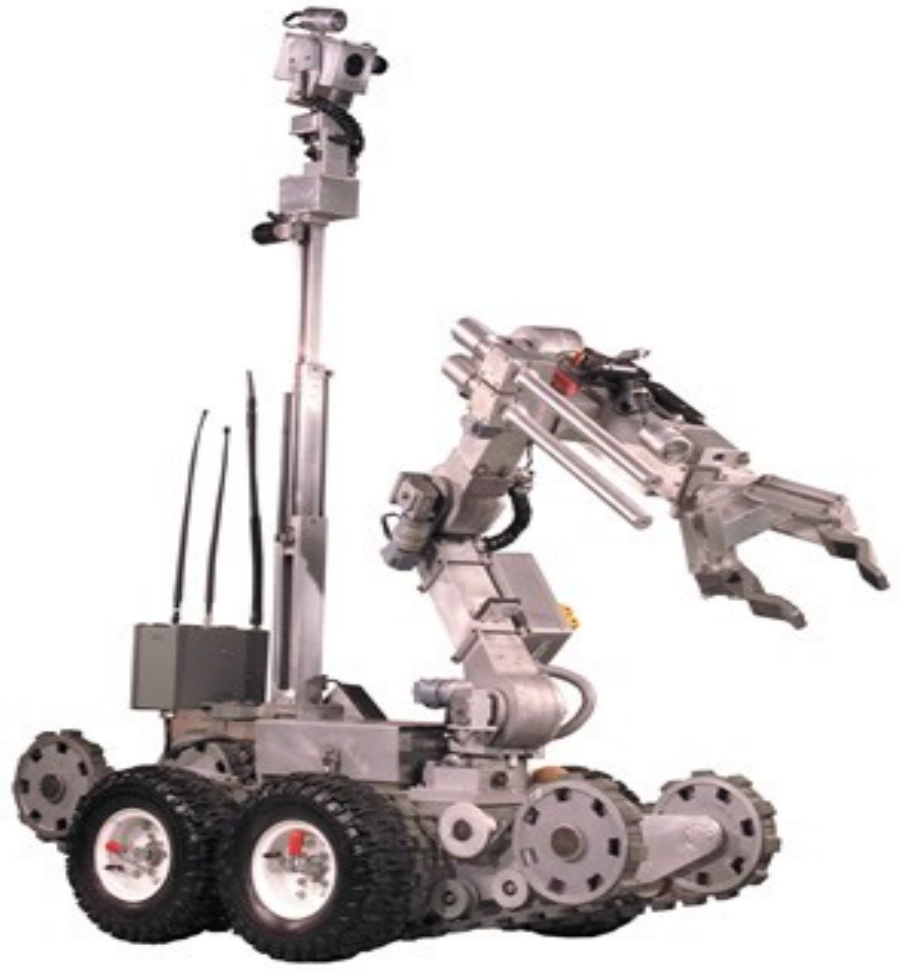

Figure no. 3: ANDROS F-6A UXO robot

With Armour for Safety
In 2003, the Ministry of Defence launched a tendering procedure for the purchase of all-terrain
military vehicles. The framework contract for the military Motor Vehicle Procurement Program (GBP)
included the potential establishment of armour protection of the vehicles. The winners of the 15-year
contract, Rába Vehicle Ltd., Daimler and MAN, guaranteed a successful implementation. The project
covers motor vehicles of categories I-III, all-terrain cars, ambulance vehicles, and lorries. The limited
liability company was tasked also to provide appropriate space in the vehicles for the necessary special
equipment (radios, NBC filters, etc.). Particular emphasis was placed on the protection of the cabin,
based on the lessons learned in Afghanistan. The partner company of the Hungarian Defence Forces
has successfully ensured the shrapnel- and projectile-resistance of the vehicles (Hungarian Defence
Forces, March 2012).




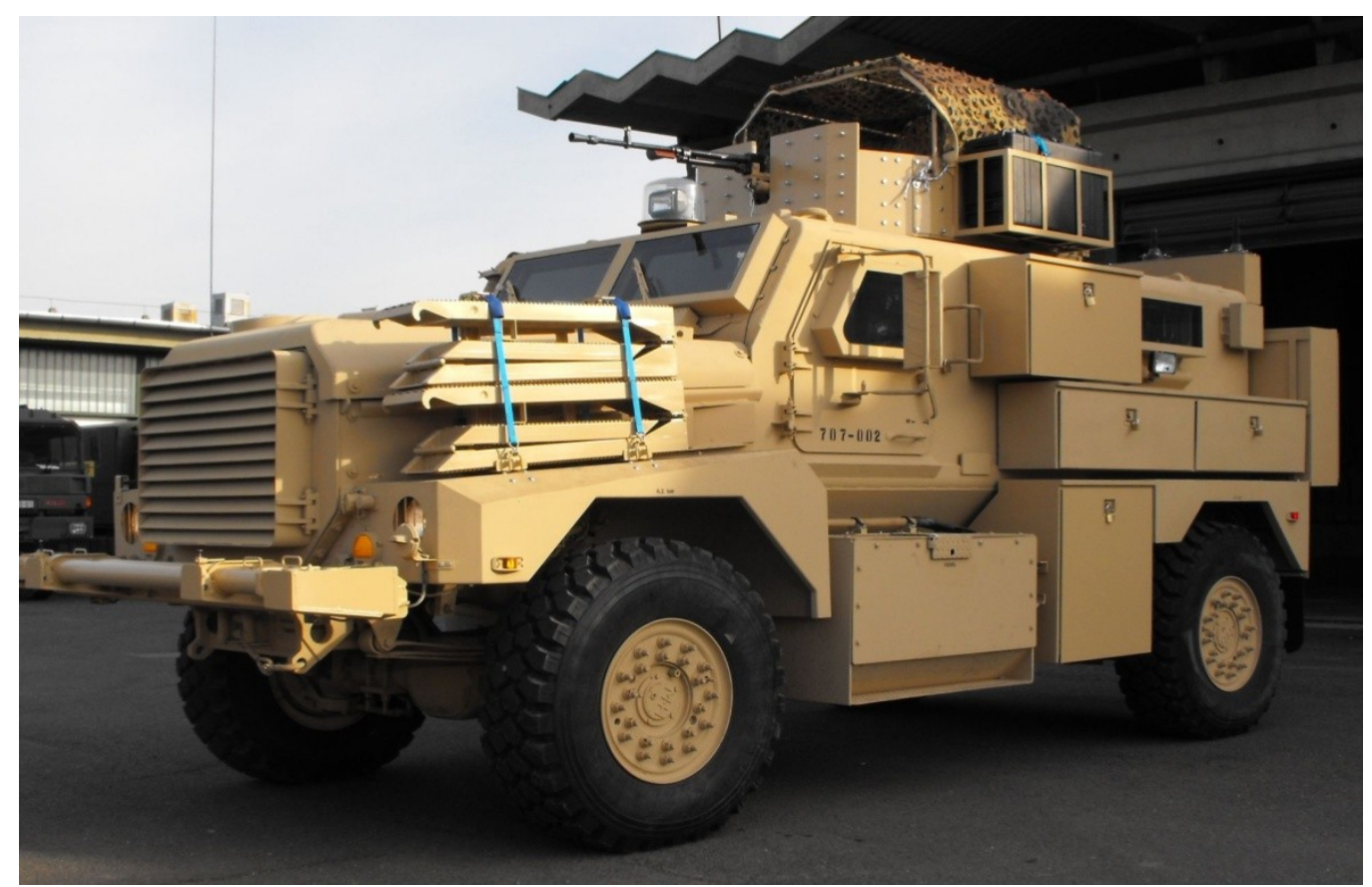

Figure no. 4: Hungarian COUGAR 4x4 for C-IED

The international and domestic efforts against improvised explosive devices also indicate that they continue to present a serious threat to both soldiers deployed and civilians living in crisis zones. Insurgents who resort to such devices quickly adapt to counter-measures. Their networks move easily and fast, and there is no particular difficulty in getting the materials necessary for producing bombs. Moreover, in failed states it is even easier to get explosive materials from illegal sources.

So, the problem is multifaceted and there is no possibility to resolve it completely, only gradual steps can be taken to protect the personnel. In countries where IED attacks have become part of everyday life, active government counteractions are essential in order to suppress the activities of insurgents. Joint development with partner countries, NATO-accredited training courses and international conferences contribute to the fight against IEDs, the exchange of experience, and the dissemination of successful countermeasures. Hungary is also involved in these activities, supporting collective defence and the protection of deployed soldiers.

\section{IED Protection}

As a result of the losses inflicted by the use of IEDs, and the increasing tendency of attacks, the protection against them got in the focus of attention in the US and other armed forces. The defence and countermeasures cover several areas: modification of tactical principles applied in convoy operations based on experience gained, detection, and development of means and methods of both passive and active defences.

An important area of the fight against IEDs is the continuous development of detection and destruction capabilities, the development of new assets, and the protection of personnel. The world's armies and arms manufacturing companies are competing with increasingly sophisticated methods used by terrorists.

The Hungarian Defence Forces also faces new challenges because of its involvement in the mission in Afghanistan and the development of Pápa Air base. Prior to 2006, the Hungarian Defence Forces UXO units basically dealt with the disarming and destruction of unexploded military ammunition, while the PRT 
necessitated their preparation for dealing with IEDs and the procurement of new means and tools.

Over the past two years, several devices have been commissioned by our specialists, such as the EOD-9 heavy bomb suit, lightweight demining ensemble (LDE), jamming devices, metal detectors, UXO robots, disrupters, manipulator arms.

\subsection{Measures to Minimize IED}

\section{Threats}

Precautions:

- Be aware of threats/the military situation in your area of operations.

- Do not allow routine processes to be recognized with regard to locations, routes, times, or procedures.

- Always be unpredictable and take advantage of deception opportunities.

- Trust your intuitions if you sense something wrong or changed.

- Monitor your environment, notice and report any deviations or irregularities. (Unusual behaviour of the population, such as markets getting suddenly vacated, changes noticed on or along roads, etc.)

- Always adhere to the required dress and vehicle codes.

- Check if the RF jammers and protective gears of electronic countermeasures (ECM) are operational.

- Make sure that objects in the vehicle are fixed, otherwise they will turn into projectiles in the event of an explosion.

- For more than 10 minutes, perform the $5 / 25$ check.

Tasks of leaders/commanders:

- Before transfers/patrols/foot-marches brief each soldier about the current IED risks. (What types/kinds of IEDs have been introduced? Where have IEDs been recently planted or deployed? Where are the hot spots? What IED indications are there?)
- Check the ECM RF jammers and protective equipment - if they are available - tuned. Check whether it is determined when to turn them on/off.

- All partners in marching need to know how the group should respond to an IED attack. - Practice.

\subsection{Behaviour at the Time of an}

\section{Attack}

Behaviour in the case of an IED assassination

Expect actions by assassins, observers (people making video recordings), further IEDs, or bursts of fire. As a leader on the spot, tailor your actions to the situation within the framework of the Rules of Engagement.

- Try to make all of your men abandon the direct zone of explosion, keep a distance.

- If there is cover, use it (remember the $5 / 25$ check).

- Organize your unit's self-defence.

- Organize the rescue of the wounded as fast as possible, in a safe vehicle with little force if possible, and deliver them in a safe area for further treatment. The leader decides on the size of the force deployed on site.

- Block the $\operatorname{road}(\mathrm{s})$ to the scene of the assassination with your own assets.

- Make an IED report and indicate the exact location of the IED attack (ICP).

- Monitor the environment and the scene of the assassination (watch out for prominent persons).

- Take the support personnel and reinforcements (UXO experts, military police, medical personnel, reserve soldiers, etc.) at the reporting point and brief them about the situation.

- Do not change anything on the scene of assassination. After the UXO-personnel leave the site, the on-site investigations are continued by the military police. 


\section{REFERENCES}

Ananics, S. A., Buznyik, P. K., \& Szuharev, A. I. (1984). Fortifikácia. Moscow: Voennoe Izdatyelsztvo, ${ }^{13 / 89735 . ~}$

Horváth, T. (2000). Possibilities of Increasing Protectiveness in FortificationCamouflage. Budapest, Hungary: Miklós Zrínyi National Defense University.

Horváth, T. (2002). Investigation of the development of fortification structures for the protection of personnel and possible directions for further development. $\mathrm{PhD}$ dissertation, Budapest, Hungary: Miklós Zrínyi National Defense University.

Horváth, T. (2018). Войсковые фортификационные сооружения для пунктов управления. Military Engineer, Vol. XIII, No.3, Budapest, Hungary: National University of Public Service.

Horváth, T., \& Padányi, J. (2006). Techniques for Peace Support Operations and Possibilities for Development - Part I. Military Logistics, Vol. 14(4), 96-130.

Horváth, T., \& Padányi, J. (2007). Technical tools for peace-support operations and opportunities for development - Part II. Military Logistics, Vol. 15(1), 68-86.

Horváth, T., \& Wanczel, G. (1995). Boosting. Szentendre, Hungary: Lajos Kossuth Military College.

Horváth, T., \& Wanczel, G. (1996). Fortification model garden in Csobánka. Technical Military Bulletin, Vol. 6 (1), 51-54.

Padányi, J., \& Horváth, T. (2001). Úkoly zenistu pri budováni ochrannych staveb a provádeni stavebni cinnosti v mirovych silách. Sbornik Vojenské Akademie v Brne Rada B: Technicke a Prirodni Vedy 1, 103-110.

Варенышев, Б. В., Дубинин, К. Н., \& Мудрагей, И. П. (1982). Военно-инженерная подготовка. Военздат.

Колибернов, Е. С., Корнев, В. И., \& Сосков, А. А. (1984). Инженерное обеспечение боя. Военздат. 